\title{
Mantle signature of the Arkhangelskaya kimberlite pipe, NW Russia
}

\author{
Marja Lehtonen ${ }^{1}$, Ilmo Kukkonen ${ }^{1}$, Hugh O'Brien ${ }^{1}$, Petri Peltonen ${ }^{1}$, Victor Ustinov ${ }^{2}$, \\ Vladimir Verzhak ${ }^{3}$ \\ 1) Geological Survey of Finland (GTK), P.O. Box 96, FI-02151, Espoo, Finland \\ 2) ALROSA Co Ltd., 128-A Nevsky pr., 193036 St.-Petersburg, Russia \\ 3) ALROSA Co Ltd., 4/7 Kuznechihinskyi pr., 163045 Arkhangelsk, Russia
}

\section{Introduction}

The kimberlites of the Zimnyi Bereg area in Arkhangelsk, NW Russia, belong to the Late Devonian, 360-380 Ma, Arkhangelsk Alkaline Igneous Province (Mahotkin et al., 2000, and references therein) (Fig. 1). Based on petrographical and geographical characteristics the kimberlites can be divided into two groups: a micaceous Western Group (Zolotitsa and Mela fields) and mica-poor Eastern Group (Kepino-Pachuga and Verkhotina-Soyana fields) that resemble South African Group II and I kimberlites, respectively. Both groups host an economic diamond deposit: the Lomonosov deposit in the Zolotitsa field and the Grib pipe in the VerkhotinaSoyana field. Kimberlites of both groups contain megacrysts (e.g. Kostrovitsky et al., 2004) and other lithosphere-derived materials, including peridotite xenoliths (Malkovets et al. 2003; Sablukova et al., 2003). Mantle xenoliths in Lomonosov are extremely altered compared to Grib. For this reason, most of the xenolith P-T estimates come from the latter (Fig. 2).

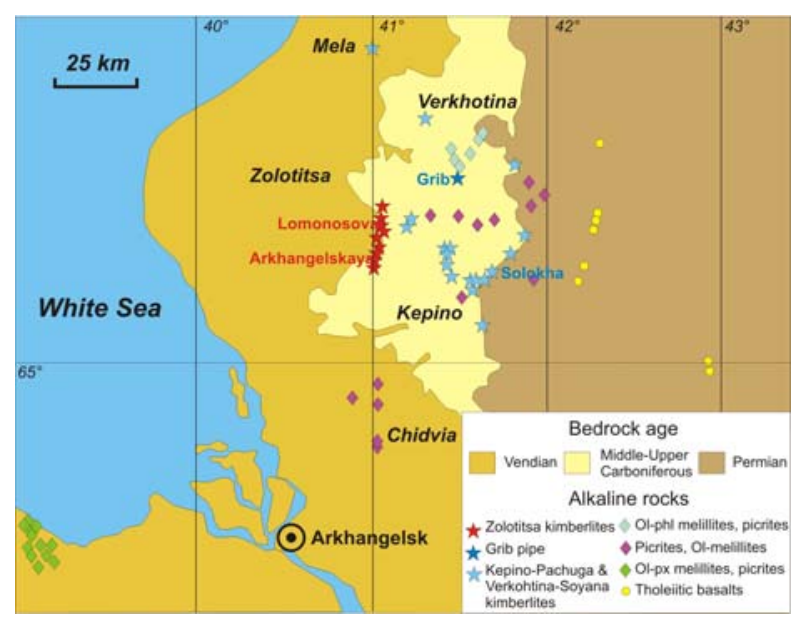

Fig.1. Simplified geological map of the Arkhangelsk alkaline igneous province. Redrawn after Krotkov et al. (2001).

The focus of this work is on the Arkhangelskaya kimberlite pipe of the Lomonosov diamond mine. The objective is to obtain additional information on the stratigraphy, compositional variability and evolutionary history of the lithospheric mantle. This study is closely linked to modelling of the $1000-\mathrm{km}$ mantle transect across the Karelian and Kuola-Kuloi cratons (Peltonen et al., this volume).

\section{Samples and analytical techniques}

Xenocryst minerals (garnet, chromite and clinopyroxene) from the Arkhangelskaya pipe were extracted from a heavy mineral concentrate provided by ALROSA Co Ltd. Mineral grains were chosen randomly and should represent the entire range of compositional populations within the kimberlite. Major element compositions were determined by a Cameca Camebax SX100 EMP at GTK and trace elements were analyzed by LA-ICP-MS at the University of Frankfurt. The garnets were classified based on their major element composition according to Grütter et al. (2004). For equilibration temperatures of garnets and chromites the Ni (Griffin et al., 1989; Ryan et al., 1996) and Zn (Ryan et al., 1996) thermometers, respectively, were applied. Equilibration pressures and temperatures of the peridotitic cpx were calculated according to Nimis \& Taylor (2000).

\section{Thermobarometry}

Single-cpx thermobarometry defines a cool continental geotherm (Fig. 2) that lies between the $36 \mathrm{~mW} / \mathrm{m}^{2}$ conductive model geotherm by Pollack \& Chapman (1977) and the $36 \mathrm{~mW} / \mathrm{m}^{2}$ geotherm by Kukkonen et al. (2003), the latter calculated for the 600 Ma Karelian Craton. In this paper, the metamorphic pressures are transformed into depth values by assuming that the pressures are representative of lithostatic pressures. Then, the petrological pressure values can be transformed into depth values using the following relationship:

$$
Z=\frac{P}{9.81 \rho_{M}}-\frac{\rho_{C}}{\rho_{M}} H+H
$$

Where $\mathrm{Z}$ is depth (m), H is thickness of crust (m), P is the pressure $(\mathrm{Pa})$ and $\rho_{\mathrm{M}}$ and $\rho_{\mathrm{C}}$ are the mantle and crust densities, respectively. For instance, applying 
$2800 \mathrm{~kg} \mathrm{~m}^{-3}$ for the crust and $3360 \mathrm{~kg} \mathrm{~m}^{-3}$ for the upper mantle density, a crustal thickness of $36 \mathrm{~km}$ (representative for the Arkhangelsk area), and a petrological pressure value of $4 \mathrm{GPa}$, the corresponding depth value is $127.4 \mathrm{~km}$.

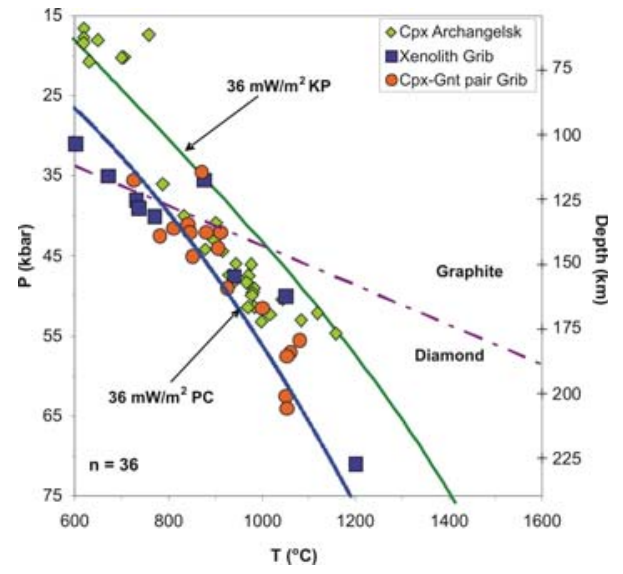

Fig. 2. P-T data from Arkhangelskaya cpx xenocrysts. Mantle xenoliths from Malkovets et al. (2003) and Sablukova et al. (2003), garnet-cpx aggregates from Kostrovitsky et al. (2004). Reference geotherms from Pollack \& Chapman (1977; PC) and Kukkonen et al. (2003; KP). The diamond-graphite transition after Kennedy \& Kennedy (1976).
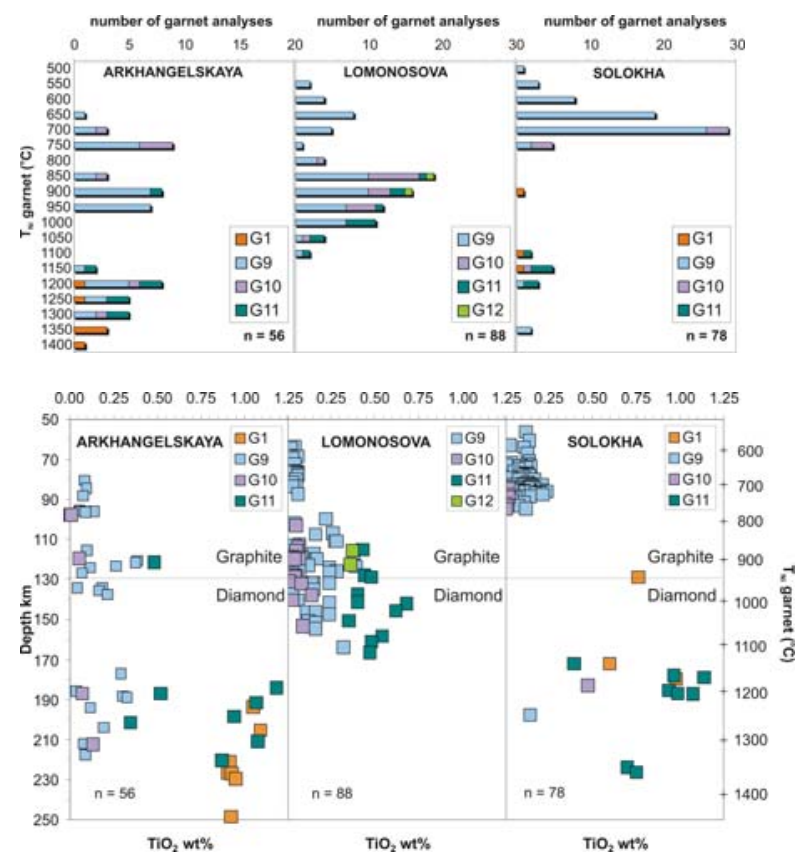

Fig. 3. Distribution of $\mathrm{T}_{\mathrm{Ni}}$ and $\mathrm{TiO}_{2}$ vs. depth for the Arkhangelskaya xenocryst pyropes. Lomonosova and Solokha data (Malkovets et al., 2007) shown for comparison.

\section{Garnet and chromite thermometry}

The $\mathrm{T}_{\mathrm{Ni}}$ data of Arkhangelskaya garnet xenocrysts show a bimodal distribution of temperatures, including a lower temperature population at $650-1000^{\circ} \mathrm{C}$ consisting of G9 and G10 garnets, and a higher temperature group at $1150-1450^{\circ} \mathrm{C}$ containing G9, G10, G1 and G11 varieties (Fig. 3). The $\mathrm{TiO}_{2}$ contents of garnets provide evidence of compositional variation within the mantle. $800^{\circ} \mathrm{C}$ corresponds to the break in $\mathrm{TiO}_{2}$ contents of garnets at approximately $100 \mathrm{~km}$ in depth. It separates low $\mathrm{TiO}_{2}(<0.2 \mathrm{wt} \%)$ shallow pyropes from a deeper horizon, $800-1000^{\circ} \mathrm{C}(100-140$ $\mathrm{km})$ exhibiting a wider range. There is also a notable gap in pyrope temperatures at $1000-1150^{\circ} \mathrm{C}$ corresponding to $140-175 \mathrm{~km}$. The deep mantle extends down to $230 \mathrm{~km}$ and contains G1 and G11 grains with high contents of $\mathrm{TiO}_{2}$ (up to $1.25 \mathrm{wt} \%$ ), which is interpreted as a melt-metasomatic signature. The Zn thermometry of the Arkhangelskaya chromites reveals continuous sampling pattern between 600$1100^{\circ} \mathrm{C}(65-165 \mathrm{~km})$, suggesting that chromites and garnets are partly derived from different mantle horizons and lithologies. Abundant chromites have diamond indicative compositions with low $\mathrm{Fe}^{3+} /\left(\mathrm{Cr}+\mathrm{Al}+\mathrm{Fe}^{3+}\right)$ (Fig. 4).

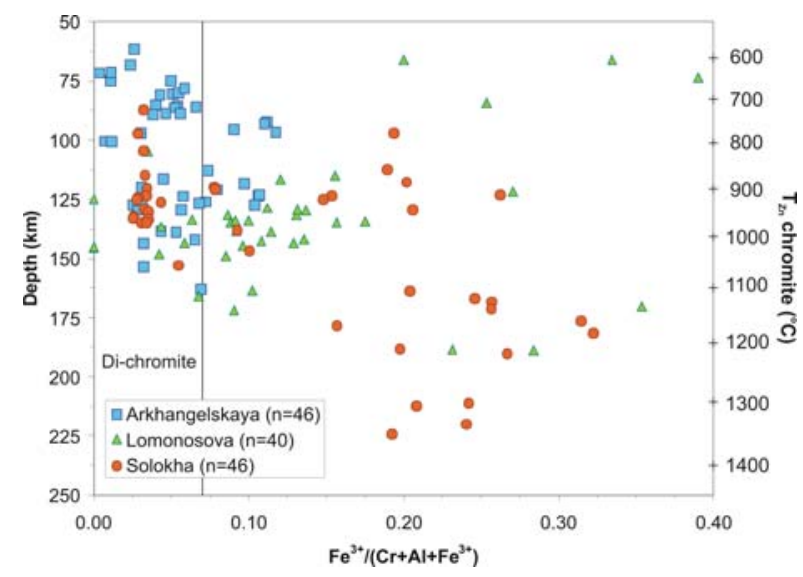

Fig. 4. $\mathrm{Fe} 3+/(\mathrm{Cr}+\mathrm{Al}+\mathrm{Fe} 3+)$ for xenocryst chromites from Arkhangelskaya. Lomonosova and Solokha data (Malkovets et al., 2007) shown for comparison.

\section{Discussion}

The mantle sampling pattern of Arkhangelskaya clearly differs from that of Lomonosova (another high-grade pipe of the Lomonosov deposit) and also from Solokha (a low-grade pipe from the Kepino field) (Figs. 1, 3 and 4). Lomonosova shows continuous mantle sampling (garnet and chromite) until ca. $180 \mathrm{~km}$ with most of the grains originating from $110-160 \mathrm{~km}$, which is also the G10 garnet bearing horizon. Solokha, on the other hand, has mostly sampled its garnets from a lowtemperature $\left(550-800^{\circ} \mathrm{C}\right)$ graphite-bearing part of the mantle at $60-100 \mathrm{~km}$, with another less prominent sampling peak at $160-210 \mathrm{~km}$. Solokha chromites display a wide range of temperatures, $700-1350^{\circ} \mathrm{C}(80$ $225 \mathrm{~km}$ ), mostly filling the wide discontinuity seen in the garnet thermometry. The sampling pattern of Arkhangelskaya is intermediate to Lomonosova and Solokha, with surprisingly few samples originating 
from the diamond stability field $(140-210 \mathrm{~km})$ considering the high-grade of the pipe. The chromite pattern resembles that of Lomonosova but the bimodal distribution of garnet is more similar to Solokha, although not as skewed towards low temperatures. Interestingly, the cpx sampling (Fig. 2) runs uninterrupted from $100 \mathrm{~km}$ to $175 \mathrm{~km}$ and accross the discontinuity at $140-175 \mathrm{~km}$ seen in the garnet data. The cpx-grains should, however, originate from garnetperidotites following the compositional criteria of Nimis \& Taylor (2000). This is strongly supported by the realistic shape of the cpx geotherm. The absence of garnet xenocrysts between 140-175 km remains, therefore, somewhat enigmatic.

The evidence from the three individual kimberlites demonstrates that there is a strong compositional variability in the mantle underlying Zolotitsa field. Chromite thermometry from Lomonosova and Arkhangelskaya pipes bears evidence of a relatively uniform chromite-bearing layer underlying the Zolotitsa field. Major differences being reflected in the presence/absence and the composition of garnet. Malkovets et al. (2007) suggested that garnet and diamond are secondary phases, created by the same metasomatic event, that included invasion of the highly refractory lithosphere by fluids from asthenospherederived melts to produce subcalcic garnet and diamond. The distribution of garnet (and diamond) in the mantle would then be controlled by the presence of ancient structural conduits and, thus, strong lateral mineralogical variation on small scales would be expected.

\section{Conclusions}

Mantle xenocrysts in the Arkhangelskaya pipe demonstrate that the lithosphere underlying the KolaKuloi Craton is comparable in depth to the adjacent Karelian Craton (Peltonen et al., this volume), and has been affected by metasomatic events, especially near the asthenosphere-lithoshpere boundary. The distribution of G10 garnets in Arkhangelskaya shows that the peridotitic diamond window extends down to $210 \mathrm{~km}$ under Zolotitsa, even though it seems that the pipe itself has sampled its diamonds only between 190$210 \mathrm{~km}$ - whereas the neighboring Lomonosova pipe has sampled its diamonds from $130-160 \mathrm{~km}$. The comparable grade of these two pipes suggests that the diamondiferous material is generously distributed within the diamond stability field. The differences between the sampling patterns of Zolotitsa (Arkhangelskaya, Lomonosova) and Kepino (Solokha) kimberlites can probably be explained by the model suggested by Malkovets et al. (2007). However, the remarkable difference evidenced by garnet composition and thermometry between the Arkahgelskaya and Lomonosova pipes, located just within a few kilometer distance from each other (Fig. 1), most likely derives from some other factors, such as differences in rheology and eruption rates of the rising kimberlite magmas - or even from inhomogeneities in the kimberlite itself.

\section{References}

Griffin, W.L., Cousens, D.R., Ryan, C.G., Sie, S.H., Suter, G.F., 1989. Ni in chrome pyrope garnets: A new geothermometer. Contrib. Mineral. Petrol. 103, 199- 202.

Grütter, H.S., Gurney, J.J., Menzies, A.H., Wintera, F., 2004. An updated classification scheme for mantle-derived garnet, for use by diamond explorers. Lithos 77, 841857.

Kennedy, C.S., Kennedy, G.C., 1976. The equilibrium boundary between graphite and diamond. J. Geophys. Res. $81,2467-2470$.

Kostrovitsky, S.I., Malkovets, V.G., Verichev, E.M., Garanin, V.K., Suvorova, LV., 2004. Megacrysts from the Grib kimberlite pipe (Arkhangelsk Province, Russia). Lithos 77, 511-523.

Kukkonen, I.T., Kinnunen, K.A., Peltonen, P., 2003. Mantle xenoliths and thick lithosphere in the Fennoscandian Shield. Phys. Chem. Earth 28 (9-11), 349-360.

Кротков, В.В., Кудрявцева, Г.П., Богатиков, О.А., Валуев, Е.П., Вержак, В.В., Гаранин, В.К., Заостровцев, А.А., Кононова, В.А., Литинский, Ю.В., Пашкевич, И.Р., Степанов, А.Н., Фортыгин, В.С., 2001. Новые технологии разведки алмазных месторождений. Москва Геoc. $310 \mathrm{c}$

Mahotkin, I.L., Gibson, S.A., Thompson, R.N., Zhuralev, D.Z., Zherdev, P.U., 2000. Late Devonian diamondiferous kimberlite and alkaline picrite (Proto-kimberlite?) magmatism in the Arkhangelsk Region, NW Russia. J. Petrol. 41, 201-227.

Malkovets., V.G., Griffin, W.L., O'Reilly, S.Y., Wood, B.J., 2007. Diamond, subcalcic garnet, and mantle metasomatism: Kimberlite sampling patterns define the link. Geology 35, 339- 342.

Malkovets, V., Taylor, L., Griffin, W., O’Reilly, S., Pearson, N., Pokhilenko, N., Verichev, E., Golovin, N., Litasov, K., 2003. Cratonic conditions beneath Arkhangelsk, Russia: Garnet peridotites from the Grib kimberlite. $8 \mathrm{IKC}$, Victoria, Extended Abstracts, $5 \mathrm{p}$.

Nimis, P., Taylor, W.R., 2000. Single clinopyroxene thermobarometry for garnet peridotites. Part I. Calibration and testing of a Cr-in-cpx barometer and an enstatite-in$\mathrm{Cpx}$ thermometer. Contrib. Min. Petrol. 139, 541-554.

Peltonen, P., Lehtonen, M.L., O'Brien, H.E., 2008. Continental mantle root deep analysis: a $1000-\mathrm{km}$ - long cross section of the Archean Karelian-Kola-Kuloi megacraton (Finland, NW Russia). This volume, No 9IKC-A-00089.

Pollack, H.N., Chapman, D.S., 1977. On the regional variations of heat flow, geotherms and lithosphere thickness. Tectonophysics 38, 279-279.

Ryan, C.G., Griffin, W.L., Pearson, N.J., 1996. Garnet geotherms: Pressure-temperature data from Cr-pyrope garnet xenocrysts in volcanic rocks. J. Geophys. Res. 101, 5611-5625.

Sablukova, L.I., Sablukov, S.M., Verichev, E.M., Golovin, N.N., 2003. Petrography and mineral chemistry of mantle xenoliths from the Grib pipe, Zimny Bereg area, Russia. Plumes and Problems of Deep Sources of Alkaline Magmatism. Proceedings of Intern. Seminar. Institute of Geochemistry, SB RAS, Habarovsk, pp. 6595. 